\title{
Clinical and Biomedical Investigation
}

Kumar N, J Clin Biomed Invest 2021, 1:1

\section{Anticipating Third Wave of Covid-19 in India. How Much Prepared We Are?}

\author{
Naveen Kumar* \\ Department of Plastic Surgery, Lady Hardinge Medical College and Associated Hospital, New Delhi -110001.
}

Correspondence to: Naveen Kumar, Department of Plastic Surgery, Lady Hardinge Medical College and Associated Hospital, New Delhi -110001. Received date: January 10, 2021; Accepted date: January 21, 2021; Published date: January 28, 2021

Citation: Kumar N (2021) Anticipating Third Wave of Covid-19 in India. How Much Prepared We Are?. J Clin Biomed Invest 1(1): pp. 1. doi: 10.52916/jcbi214002 Copyright: (C2021 Kumar N. This is an open-access article distributed under the terms of the Creative Commons Attribution License, which permits unrestricted use, distribution and reproduction in any medium, provided the original author and source are credited.

\section{Editorial}

$\mathrm{T}$ he second wave of Covid -19 in India has made us witness as to how negligence from the part of everyone of us, be it people, Government or policy makers of healthcare system might bring the unwanted disaster in the form of Covid Tsunami. This has made us to see never ending queues of patients, relatives standing for hours for the want of hospital beds, oxygen, essential medicines and lastly but unfortunate for their turn for the cremations of loved ones. But now we can see the number of active cases are declining across the country. Amidst this positive observation in regard of second wave there is speculation erupting about the Covid third wave. We can appreciate a similarity in the way that the noble corona virus behave with the Spanish flu that had shaken the world in 1918. It had resulted in three waves with second wave was most deadly and long lasting than the other two waves. During the first wave where the infection was mostly of mild severity we had seen the disease affecting the elderly and immune-compromised patients more. In contrast to this, second wave resulting from mutant strains affected the younger population more and it was of larger severity with high mortality rate. Scientists and experts are now anticipating the third wave, taking the lesson from the Spanish flu and we must be better prepare for it.

In order to prepare ourselves from a expected third wave of Covid-19, we shouldn't repeat mistakes that we made during previous waves. We should refrain ourselves from dismantling our enhanced healthcare facilities, there should not be any sorts of shortage of oxygen, hospital beds, and drug that we have already witnessed. We must have an aggressive containment measure comprising of a really strong and pro-active surveillance system. This can be achieved by increasing the capacity of the existing surveillance system by identifying active cases early. We

must ensure that we should follow "social vaccine" of proper masking, avoid indoor gatherings, and proper sanitization. Our vaccination programme needs a boost. We should vaccinate a large section of people before any third wave hits us. The more we vaccinate, the better prepared we are. As medical professionals, it must be ensured that proper scientific protocol must be implemented while handling Covid-19 cases. And last but not the least efforts must be made to fill up vacancies seen in our public health system, especially for frontline healthcare workers.

As it is anticipated that the young children are more vulnerable to the forthcoming third wave, efforts are to be sought in order to start vaccination of the younger children in our country. Trials for which has already been started in India and across the world. Till the time vaccine is made available, the resources are to be mobilized to build up healthcare facilities catering the vulnerable age group in this third wave such as building up of more paediatric wards, paediatric ICU's, training of healthcare personals in handling the emergencies for expected third wave .In addition to these efforts, more and more paediatric covid care centers must be set up at various parts of the country. Equally important is making arrangements for rehabilitation centers for the orphans. Countries like US, Singapore and UAE have already started vaccinating the children in age group between 12 to 15 years with Pfizer-BioNTech Covid vaccine. It's a high time that the government in India must consider for allowing "expedited approval pathway" to the companies like Pfizer for their Covid-19 vaccine for children. All these combined efforts from everyone may ensure that the country and world may remain well equipped against these subsequent waves of this deadly virus and pave the path of the triumph in the near future. 